\title{
ESTIMATING FISCAL SPACE: AN EMPIRICAL STUDY ON TURKEY
}

\author{
Fatih AKBAYIR ${ }^{1}$
}

\author{
Ahmet Burçin YERELi ${ }^{2}$
}

\begin{abstract}
In this study, Turkey's fiscal space is estimated by using Ostry et al. approach. It is aimed to contribute to literature by estimating fiscal space of a developing country for the first time with this approach. At first, fiscal reaction function and interest rate - growth rate differential are estimated for Turkey. Debt limit is determined by combining the reaction function and the differential. Thereafter, it is reached to Turkey's fiscal space subtracting current debt (in percent of GDP) from the debt limit. Accordingly, when all risks are ignored, Turkey's fiscal space is approximately $37 \%$ of GDP. The main reason of this relatively high ratio are realizing primary surpluses thanks to the fiscal discipline and providing high growth rates which reduce debt/GDP ratio for many years. But, given the risks arising from Turkey's structural economic characteristics, it is observed that Turkey's fiscal space decreased significantly. Accordingly, governments in Turkey should pay attention to contingent liabilities about treasury guarantees given in the direction of the PPP investment model and social security deficits. Because these factors negatively affect the fiscal space. In this respect, reducing the risk of exploitation of the fiscal space requires preserving continuity of high level of primary balance and some structural reforms, mainly related to the current account deficit.
\end{abstract}

Keywords: Fiscal reaction function, differential, debt limit, fiscal space, Ostry et al. approach, Turkey

JEL Code: E62, H62, H69.

\section{Introduction}

In the study, it is aimed estimating Turkey' fiscal space through Ostry et al. approach. The study contributes to literature by estimating fiscal space of a developing country for the first time with this approach. At first, fiscal reaction function (the reaction of primary balance to public debt) is estimated for Turkey. The function is estimated through Ordinary Least Squares method with annual data from 1986 to 2018. Following, interest rate - growth rate differential is estimated by using long term government bond interest rates and growth rates in the last decade for Turkey. The diferantial equals to subtracting average economic growth rates from average bond intereset rates. Debt limit is determined by combining the reaction function and the differential. Thereafter, it is reached to Turkey's fiscal space subtracting current debt to GDP (in percent) from the debt limit.

\section{Literature Review}

There are many methods of estimating fiscal space in the literature. The fiscal space of countries is estimated with these methods (Nerlich \& Reuter, 2015: 4). Ostry et al. approach is one of them. Zandi et al. (2011); Bastos \& Pineda (2013); Ghosh et al. [2013(a)]; Ghosh et al. [2013(b)]; Hajnovic \& Zeman (2013); Kim (2015); Nerlich \& Reuter (2015); and Adedeji et al. (2016) use

\footnotetext{
1 Res. Asst., Karamanoglu Mehmetbey University, akbayirfatih@gmail.com (corresponding author)

2 Prof., Hacettepe University, ahmetburcin@gmail.com
} 
this approach while estimating the fiscal space of countries. They Assoc.d also the fiscal space estimated through this approach with other concepts.

\section{Data}

Estimating the fiscal space through Ostry et al. approach requires estimating the fiscal reaction function. Primary balance to GDP (in percent), debt to GDP (in percent), output gap, government expenditure gap, trade openness, inflation [consumer price index (cpi)], age dependency, political stability and IMF arrangements are used while estimating Turkey's the fiscal reaction function from 1986 to 2018. Following, last ten years average of long term government bond interest rates and average of economic growth rates in the last decade are used while estimating interest rate - growth rate differential for Turkey. Also, inflation rates are used in order to convert nominal interest rates to real interest rates.

\section{Methodology}

According to Ostry et al. (2010), the fiscal reaction function should be estimated to be able to estimate the fiscal space of a country. Accordingly, fiscal reaction function of Turkey is estimated through Ordinary Least Squares method from 1986 to 2018. Variables in the function have time series features. Whether a time series variable is non-stationary (whether it has a unit root) should be tested through unit root tests. Because non-stationary series (it has a unit root) cause mistake results (Wooldridge, 2013: 636). Accordingly, time series variables in the function for Turkey are tested in this respect and some variables are edited according to test results. In addition to this, the model is tested in terms of some assumptions. Because these assumptions are necessary to be able to estimate the reaction function through Ordinary Least Squares method. The function is edited according to test results.

Following, interest rate - growth rate differential is estimated for Turkey. Accordingly, it is reached to the differential by subtracting average economic growth rates from average bond intereset rates in the last decade for Turkey. In addition to this, another diferantial is estimated through endogenous interest rates. Because the market interest rate doesn't take account of the rising default as debt approaches its limit.

Finally, it is reached to debt limit by combining the reaction function and the differential through various formulations derived from intertemporal budget constraint. Thereafter, Turkey's fiscal space is estimated by subtracting current debt to GDP (in percent) from the debt limit. Also, Turkey's fiscal space is estimated taking account the risky environment with endogenous interest rates. Accordingly, the fiscal space estimated with the risky environment is less than risk free.

\section{Results}

Firstly, fiscal reaction function for Turkey is estimated. Thus, $\mu$ could be determined;

$$
\begin{aligned}
& \mathrm{pb}=0.0796 * \mathrm{ld}-0.0032 * \mathrm{ld} \wedge 2+0.1310 * \text { og }-0.3438 * \mathrm{geg}-0.1532 * \text { to }-0.1647 * \mathrm{ad}+15.3848 \\
& \mu=0.1310 * \text { og }-0.3438 * \text { geg }-0.1532 * \text { to }-0.1647 * \mathrm{ad}+15.3848 \\
& \mu=0.1310 * 4,06-0.3438 * 8,00-0.1532 * 28,43-0.1647 * 71,67+15.3848 \\
& \mu=-2,9933
\end{aligned}
$$


pb is primary balance to GDP (in percent); Id is lagged debt to GDP (in percent); og is output gap; geg is government expenditure gap; to is trade openness; ad is age dependency; and $\mu$ is all determinants of the primary balance other than lagged debt.

Secondly, two different interest rate - growth rate differential for Turkey is estimated. Both market interest rates and endogenous interest rates are used while estimating differential. For example;

differential (with market interest rates) $=>\% 0,85-\% 5,39=-\% 4,54$

Lastly, the debt limit ( $\bar{d}$ ) is determined by combining the fiscal reaction function and the interest rate - growth rate differential through the following formulation derived from intertemporal budget constraint;

$\overline{\mathrm{d}}=\frac{-0,0299}{-0,0454} \times 100$

Following, Turkey's fiscal space is estimated by subtracting current debt (2018) to GDP (in percent) (29\%) from the debt limit (66\%). Accordingly, Turkey's fiscal space is $37 \%$ if risks are ignored. Also, Turkey's fiscal space is estimated taking account the risky environment with endogenous interest rates. According to Table 1, Turkey's fiscal space is $10 \%$ if the probability of default $(50 \%)$ is taken into account. And, Turkey has no fiscal space if the probability of default (65\%) is taken into account.

Table 1: Turkey's Debt Limit and Fiscal Space (\% of GDP)

\begin{tabular}{|c|c|c|c|c|}
\hline Probability of Default & $\begin{array}{c}\text { Interest Rates } \\
\text { (Nominal) }\end{array}$ & Debt Limit & $\begin{array}{c}\text { Current Debt } \\
\text { (2018) }\end{array}$ & Fiscal Space \\
\hline $\begin{array}{c}0 \% \\
\text { (risk free) }\end{array}$ & $10,40 \%$ & $66 \%$ & $29 \%$ & $37 \%$ \\
\hline $50 \%$ & $21,44 \%$ & $39 \%$ & $29 \%$ & $10 \%$ \\
\hline $65 \%$ & $30,90 \%$ & $15 \%$ & $29 \%$ & $0 \%$ \\
\hline
\end{tabular}

\section{Conclusion}

When all risks are ignored, Turkey's fiscal space is approximately $37 \%$ of GDP. The main reasons of this relatively high ratio are realizing primary surpluses in reaction to fiscal discipline and providing high growth rates which reduce debt/GDP ratio for many years. But, given the risks arising from Turkey's structural economic characteristics, it is observed that Turkey's fiscal space decreased significantly. For example, it is seen that if government's default probability increases by half, Turkey's all fiscal space is exhausted. Accordingly, governments in Turkey should pay attention to contingent liabilities about treasury guarantees given in the direction of the PPP investment model and high level of social security deficits. Because these factors negatively affect the fiscal space. In this respect, reducing the risk of exploitation of the fiscal space requires preserving continuity of high level of primary balance and some structural reforms, mainly related to the current account deficit. 


\section{References}

Adedeji, O., Ahokpossi, C., Battiati, C. \& Farid, M. (2016). "A Probabilistic Approach to Fiscal Space and Prudent Debt Level: Application to Low-Income Developing Countries", IMF Working Paper, WP/16/163, International Monetary Fund, Washington, D.C.

Bastos, F. \& Pineda, E. (2013). "Fiscal Space of Brazilian States", Inter-American Development Bank Discussion Paper, IDB-DP-310, Inter-American Development Bank, Washington, D.C.

Ghosh, A., Kim, J., Mendoza, E., Ostry, J. \& Qureshi, M. (2013a). “Fiscal Fatigue, Fiscal Space and Debt Sustainability in Advanced Economies", The Economic Journal, 123, pp. F4-F30.

Ghosh, A., Ostry, J. \& Qureshi, M. (2013b). "Fiscal Space and Sovereign Risk Pricing in a Currency Union", Journal of International Money and Finance, 34, pp. 131-163.

Hajnovič, F. \& Zeman, J. (2013). "Fiscal Space in the Euro Zone", Narodna Banka Slovenska, 21(2), pp. 9-14.

Nerlich, C. \& Reuter, H. (2015). "Fiscal Rules, Fiscal Space and Procyclical Fiscal Policy”, European Central Bank Working Paper Series, 1872, European Central Bank, Frankfort.

Ostry, J., Ghosh, A., Kim, J. \& Qureshi, M. (2010). "Fiscal Space”, IMF Staff Position Note, SPN/10/11, International Monetary Fund, Washington, D.C.

Wooldridge, J. M. (2013). Ekonometriye Giris - Modern Yaklasim (Ebru Caglayan, translation). Ankara: Nobel Akademi Publishing (2009).

Zandi, M., Cheng, X. \& Packard, T. (2011). “Fiscal Space”, Moody's Analytics Special Report, Moody's Analytics, New York. 